\title{
TINGKAT KEPUASAN KONSUMEN TERHADAP SISTEM PEMESANAN TIKET ONLINE PADA MASKAPAI GARUDA INDONESIA DI DENPASAR BALI
}

\author{
Ni Putu Ayu Savitri \\ I Wayan Suardana \\ I Nyoman Sudiarta \\ Email : putuayusavitri@rocketmail.com \\ PS. S1 Industri Perjalanan Wisata \\ Fakultas Pariwisata UNUD
}

\begin{abstract}
This study discsess the level of the research about the level of customer satisfaction with the online ticket booking system on Garuda Indonesia in Denpasar Bali. This study aims to determine user satisfaction online ticket booking system. The research method used is the Cartesian diagram.

These results indicate that the level of customer satisfaction was $88.68 \%$. It can be concluded that consumers were less satisfied with the performance or services provided from an online ticket booking system suitability Garuda Indonesia karen prsentase not be above $100 \%$ or equal to $100 \%$. Based on the characteristics can be in simpulakan that $62.5 \%$ of consumers men-men and $45 \%$ of consumers are over 45 years old.

Based on these results, it can be concluded some suggestions that can be beneficial for the airline Garuda Indonesia there; ah as follows: to put the choice should request special ntuk with disabilities as can order service korsi wheel when booking tickets online. Because Garuda Indonesia is not included in the ticket booking system guarantees and insurance ll clarify what is in the can and that the rights of every passenger.
\end{abstract}

Keywords: Satisfaction, Customer, Service Quality.

\section{PENDAHULUAN}

Dalam memberikan kemudahan pada sistem pemesanan tiket pada maskapai penerbangan maka dibuatkanlah sistem pemesanan tiket secara online atau kerap di sebut Electronic ticket (e-ticket) yang memberikan kemudahan bagi orang-orang yang menginginkan tiket untuk penerbangan tanpa harus beranjak dari rumah atau kantor untuk mencari travel agent. Dengan e-ticket, berbagai kemudahan didapatkan, dan mendatangkan keuntungan bagi maskapai penerbangan.

E-ticket membawa informasi yang sama dengan tiket kertas. Perbedaan utama adalah terletak pada database komputer maskapai penerbangan tersebut. E-ticket adalah catatan electronic resevasi perjalanan, mengandung informasi, seperti tanggal, waktu, berat bagasi, besar biaya perjalanan dan kelas kursi. Sewaktu check-in di bandara, penumpang perlu menunjukkan e-ticket disertai identitas diri (KTP/SIM), setelah itu dari pihak maskapai akan memberikan boarding pass untuk masuk ke ruang tunggu dan pesawat. $E$ ticket memberikan keuntungan baik penumpang maupun maskapai penerbangan, mulai dari aspek keamanan, fleksibilitas, biaya, dan kenyamanan. Selain itu e-ticket memberikan stkonsumenrd jaminan yang sama dengan tiket kertas.

\section{TINJAUAN KONSEP}

Kepuasan konsumen adalah sejauh mana manfaat sebuah produk dirasakan (perceived) sesuai dengan apa yang diharapkan pelanggan (Amir, 2005). Kotler (2000) mengatakan bahwa kepuasan konsumen merupakan tingkat perasaan seseorang setelah membandingkan antara kinerja produk yang ia rasakan dengan 
harapannya. Kepuasan atau ketidakpuasan konsumen adalah respon terhadap evaluasi ketidaksesuaian atau diskonfirmasi yang dirasakan antara harapan sebelumnya dan kinerja aktual produk yang dirasakan setelah pemakaian (Tse dan Wilson dalam Nasution, 2004)

Berdasrkan beberapa konsep tentang kepuasan pengguna jasa, kepuasan pengguna jasa dalam penelitian ini adalah suatu perasaan senang dan kecewa yang dirasakan oleh pengguna jasa setelah membandingkan kualitas pelayanan/kinerja dari pengelola sistem pemesanan tiket onine dengan harapan - harapan yang diinginkan pengguna jasa selama berada di daerah tujuan.

Perilaku konsumen jasa tidak berbeda dengan perilaku konsumen barang karena pembeli atau pengguna barang dan jasa hanya merupakan suatu sasaran untuk memenuhi kebutuhan. Teori yang mempelajari tentang berbagai faktor yang mempengaruhi konsumen dalam membeli barang atau jasa inilah yang disebut sebagai model perilaku konsumen. Beberapa faktor yang mempengruhi keputusan membeli seperti kebudayaan, sosial, pribadi dan psikologi ( Mowen, 2001)

Pengertian konsumen adalah setiap orang pemakai barang dan atau jasa yang tersedia dalam masyarakat, baik bagi kepentingan diri sendiri, keluarga, orang lain, maupun makhluk hidup lain dan tidak untuk diperdagangkan. Pengertian konsumen menurut Philip Kotler (2000) konsumen adalah semua individu dan rumah tangga yang membeli atau memperoleh barang atau jasa untuk dikonsumsi pribadi.

$\begin{array}{rrr}\text { E-ticketing atau electronic } & \text { ticketing } \\ \text { adalah merupakan } & \text { cara } & \text { untuk }\end{array}$ mendokumentasikan proses penjualan dari aktifitas perjalanan pelanggan tanpa harus mengeluarkan dokumen berharga secara fisik ataupun paper ticket. Semua informasi mengenai electronic ticketing disimpan secara digital dalam sistem komputer milik airline. Sebagai bukti pengeluaran E-ticket, pelanggan akan diberikan Itinerary Receipt yang hanya berlaku sebagai alat untuk masuk ke dalam bandara di Indonesia yang masih mengharuskan penumpang untuk membawa tkonsumen bukti perjalanan. E-ticketing (ET) adalah peluang untuk meminimalkan biaya dan mengoptimalkan kenyamanan penumpang. E-ticketing mengurangi biaya proses tiket, menghilangkan fomulir kertas dan meningkatkan fleksibilitas penumpang dan agen perjalanan dalam membuat perubahanperubahan dalam jadwal perjalanan.

\section{METODE PENELITIAN}

Untuk memberi batasan dan penegasan permasalahan yang diteliti dan untuk menghindari terjadinya perbedaan interprestasi terhadap variable yang dikaji, maka variable tersebut sebagai berikut :

1. Bukti langsung (tangible), meliputi fasilitas, perlengkapan, dan sarana komunikasi.

2. Kekonsumenan(reliability), kemampuan memberikan pelayanan melalui sistem seperti pencarian time table dan sistem pemesanan yang dapat di lakukan pada wesite maskapai Gruda Indonesia.

3. Daya tanggap (responsiveness), yaitu kemampuan responsibel sistem dalam menanggapi gangguan da kemudahan dalam aksesnya.

4. Jaminan (assurance), mencakup asuransi maupun jaminan yang didapat.

5. Empati (emphaty), meliputi ketersediaan layanan untuk penyandang cacat maupun orang yang sedang sakit.

\section{HASIL DAN PEMBAHASAN}

\section{Tingkat Kepuasan Pelayanan Dengan Kepuasan Konsumen Sistem Pemesanan Tiket Secara Online}

Hasil penelitian yang telah dilakukan melalui penyebaran kuisioner sebanyak 40 kuisioner kepada konsumen maskapai Garuda Indonesia secara umum cukup memuaskan namun perlu di tingkatkan lagi sedangkan untuk kepentingan secara umum adalah aspek yang penting untuk konsumen sistem pemesanan tiket online di Maskapai Garuda Indonesia di Denpasar - Bali. Adapun analisis dari masing - masing indikator pelayanan sebagai berikut:

\section{Fasiitas yang diberikan}

Perhitungan yang di peroleh menunjukan bahwa penilaian konsumen sistem pemesanan tiket secara online terhadap fasilitas yang diberikan menunjukan bahwa 75 $\%$ sangat puas dan $25 \%$ puas. Dimana di dapatkan bahwa sebanyak $65 \%$ menyatakan sangat penting, $25 \%$ menyatakan penting dan $10 \%$ cukup penting. Dapat diperoleh bahwa konsumen cukup puas denga fasilitas yang 
ditawarkan dengan kepentingan yang cukup tinggi.

\section{Kerapian letak icon}

Kerapian tata letak icon pilihan mendapat persentase sebanyak $17,5 \%$ merasa sangat puas , $30 \%$ puas , $32,5 \%$ cukup puas, $15 \%$ tidak puas dan $7,5 \%$ sangat tidak puas dimana $37,5 \%$ menyatakan bahwa hal tersebut sangat penting, $30 \%$ penting, 32,5\% cukup penting dimana aspek sangat penting yang dirasakan oleh konsumen sistem pemesanan tiket secara online dianggap cukup puas dengan kerapian tata letak icon yang ada di website maskapai Garuda Indonesia.

\section{Kemudahan mencari time table}

Kemudahan dalam pencarian time table di rasa sangat penting karena persentase menunjukkan 72,5\% sangat penting , 17,5\% penting, $10 \%$ cukup penting dengan tingkat kepuasan $62,5 \%$ untuk sangat puas , 27,5\% puas , $10 \%$ cukup puas.Dengan demikian membuktikan bahwa sistem pencarian time table dirasa sangat penting oleh konsumen.

\section{Sistem pemesanan tiket}

Sistem pemesanan tiket yang dimaksud adalah informasi maupun sistem mengenai langkah - langkah dalam melakukan pemesanan tiket dimana $62,5 \%$ konsumen merasakan hal tersebut sangat penting, 22,5\% penting, $15 \%$ cukup penting dan $37,5 \%$ yang merasa sangat puas, $55 \%$ puas $5 \%$ cukup puas dan $2,5 \%$ tidak puas. Ketidak puasan ini dikarenakan terkadang terjadi gangguan dimana konsumen tidak dapat membuka web terutama di jam kerja.

\section{Kemampuan sistem dalam menanggapi gangguan}

Kemampuan sistem yang dinilai adalam kemampuan respon yang cepat terhadap baigan penting maupun pilihan penting yang harus diisi namun terlupakan oleh penguna. Konsumen merasa sangat puas terhadap kecepatan respon bila adanya kelalaian dalam pengisian kolom. Sebanyak 82,5 \% menyatakan sangat puas dan $17,5 \%$ puas dan $17 \%$ untuk sangat penting , $20 \%$ penting dan $5 \%$ cukup penting. Sebagian responden merasa puas karena terkadang mereka lupa menulis no telpon maupun terjadnya kesalahan pengetikan nama.
Kemudahan akses pencarian hal yang
diinginkan (special request)

Kemudahan yang dimaksud adalah permitaan lain selain pemesanan tiket pesawat seperti pemesanan hotel mapun hal yang butuhkan oleh konsumen .72,5\% konsumen merasa hal tersebut sangat penting, 27,5\% penting dan $67,5 \%$ yang menyatakan puas , $25 \%$ puas daan $7,5 \%$ cukup puas.

\section{Jaminan yang diberikan}

Jaminan kecelakaan mapunun menganai feed back yang di berikan bila terjadinya cancel dll dirasa sangat penting dimana memperoleh persentase sebanyak 87,5 \%\% konsumen merasa hal tersebut sangat penting, 7,5\% penting, $5 \%$ cukup penting dan $20 \%$ menyatakan sangat puas 22,5 puas , $50 \%$ cukup puas $5 \%$ tidak puas dan $2,5 \%$ dangat tidak puas. Hal ini dikarenakan kurang dtailnya jaminan yang dierikan namun rata rata konsumen merasa puas.

\section{Special request untuk penykonsumenng cacat atau orang sakit}

Special request yang dimaksud adalah fasilitas yang dapat diberikan untuk penykonsumenng cacat maupun orang yang sedang sakit. $85 \%$ konsumen merasa hal tersebut sangat penting, 5\% penting, $10 \%$ cukup penting. Akan tetapi hanya $10 \%$ yang merasa sangat puas, $32,5 \%$ cukup puas , $55 \%$ tidak puas dan 2,5\% sangat tidak puas. Hal ini dikarenakan tidak adanya pilihan yang dapat dipilih jika ingin mendapatkan fasilitas lebih seperti kursi roda maupun yang fasilitas lain.

\section{Analisis Indikator Pelayanan Pada Diagram Cartesius}

Selanjutnya agar dapat mengetahui letak faktor - faktor diagram Cartesius maka terlebih dahulu menentukan dua buah titik $\underline{\underline{X}}$ dan $\underline{\underline{Y}}$ yang berpotongan membatasi empat bagian dalam diagram Cartesius . Perhitungan $\underline{\underline{X}}$ sebesar 4,06 merupakan rata - rata dari rata - rata skor tingkat kerja seluruh indikator yang mempengaruhi seputusan konsumen. Dan perhitungan $\underline{\underline{Y}}$ sebesar 4,50 yaitu rata - rata skor tingkat kepentingan dan seluruh indikator yang mempengaruhi kepuasan konsumen .

Terlihat bahwa dari indikator indikator pelayanan yang mempengaruhi kepuasan konsumen yang menggunakan sistem pemesanan tiket online pada maskapai Garuda Indonesia terbagi kedalam empat 
bagian dalam diagram Cartesius. Adapun penjelasan dari diagram tersebut adalah sebagai berikut:

Garis y diagram tersebut merupakan batasan tingkat kepentikngan masing - masing factor atau indikator pelayanan menurut persepsi konsumen. Garis tersebut membag menjadi 2 bagian yaitu hasil pengukuran terhadap indikator pelayanan di atas garis Y, maka indikator dari pelayanan tersebut dianggap penting oleh konsumen antara lain adalah :a. Kemudahan pencarian time table (3), b Kemampuan sistem dalam menanggapi gangguan (5), c.Kemudahan akses pencaian hal yang diinginkan (6), d. Jaminan yang diberikan (7), e Special request (8)

Jika hasil pengukuran terhadap indikator pelayanan terletak di garis $\mathrm{Y}$, maka indikator tesebut dianggap kurang penting oleh konsumen. Indikiator - indikator yang dianggap kurang penting oleh konsumen antara lain : a. Fasilitas yang diberikan (1), b.Kerapian letak icon (2), c . Sistem pemesanan tiket (4). Letak indikator indikator dalam diagram kartesius tersebut di jelaskan sebagai berikut :

1. Kuadran A

Pada kuadran A menunjukan indikator yang mempengaruhi kepuasan konsumen. Indikator dala kuadran ini perlu mendapat prioritas dalam pelaksanaanya oleh maskapai Garuda Indononesia. Sedangkan kinerja ataupun pelaksanaannya masih belum memuaskan.Adapun indikator tersebut adalah jaminan yang diberikan (7) dan special request (8)

2. Kuadran B

Pada kuadran B menunjukan indikator yang mempengaruhi kepuasan konsumen. Indikator dalam kuadran ini dirasa penting oleh konsumen dan telah sesuai dengan apa yang di harapkan konsumen .Oleh karena itu perlu dipertahankan oleh pihak maskapai Garuda Indonesia.Adapun indikator yang berada pada kuadran B sebagai berikut:a. Fasilitas yang diberikan (1), b.Kemudahan pencarian time table (3), c. Kemampuan sistem dalam menanggapi gangguan (5),d.Kemudahan pencarian hal yang diinginkan (6)

3. Kuadran $\mathrm{C}$

Pada kuadran $\mathrm{C}$ indikator yang mempengaruhi kepuasan wisatawan dinilai kurang penting oleh konsumen, sedangkan kinerjanya oleh maskpai
Garuda Indonesia bisa di katakana cukup. Indikator yang termasuk dalam kuadran ini adalah kerapian letak icon (2)

4. Kuadran D

Pada kaudran D indikator yang mempengaruhi kepuasan konsuemn yang dinilai kurang penting oleh konsumen namun pelaksanaanya berlebihan. Indikator yang terdapat pada kuadran D adalah sistem pemesanan tiket online (4)

\section{SIMPULAN DAN SARAN Simpulan}

Berdasarkan pembahasan mengenai tingkat kepuasan konsumen terhadap sistem pemesanan tiket online pada maskapai penerbangan Garuda Indonesia di Denpasar Bali dari jumlah responden 40 orang maka dapat diambil kesimpulan sebagai berikut :

1. Dari hasil perhitungan tingkat kepuasan konsumen yang menggunakan sistem pemesanan tiket secara online, seusai dengan tingkat kesesuaian antara rata rata skor dan rata - rata tingkat kepentingan di peroleh hasil di bawah 100 $\%$ maka hal ini di katakana bahwa konsumen masih merasa belum cukup puas mengenai kinerja dari setiap indikator yang ditanyakan.

2. Berdasarkan diagram Cartesius maka diperoleh indikator - indikator yang dinilai penting namun perlu di tingkatkan lagi yaitu jaminan yang diberikan (7) dan special request (8)

3. Dari hasil perhitungan karakteristik konsumen di peroleh bahwa laki - laki lebih sering menggunakan sistem pemesanan tiket online ketimbang perempuan dan usia 45 keatas memeliki kecendrungan lebh sering dari pada usia yang di bawahnya walau tidak terlalu jauh dengan usia $36-45$ tahun.

\section{Saran}

Berdasarkan simpulan tersebut, maka dapat di kemukakan beberapa saran yang sekiranya dapat bermanfaat bagi maskapai Garuda Indonesia :

1. Diharapkan untuk Garuda Indonesia untuk meningkatkan pelayanan maupun kinerja dari website pemesanan tiket secara online karena konsumen belum merasakan puas dengan kinerja dari Garuda Indonesia.

2. Hendaknya mencantukan pilihan special request ntuk penyandang cacat seperti 
dapat memesan service kursi roda saat melakukan pemesanan tiket secara online. Karena Garuda Indonesia belum menyertakan ini pada sistem pemesanan tiket online. Serta memperjelas jaminan maupun asuransi apa saja yang di dapat.

\section{DAFTAR PUSTAKA}

Amir, M. Taufiq. 2005. Dinamika Pemasaran: Jelajahi \& Rasakan. Jakarta: PT. RajaGrafindo Persada.

Godang , 2012 . Analisis Tingkat Kepuasan Wisatawan Terhadap Pelayanan Reservasi Tiket Pesawat Pada PT. Untung Bersama Sama (UBS) Tour And Travel Denpasar - Bali . Denpasar : Prgram Studi Industri Perjalanan Wisata Universitas Udayana

Hidayana, Fransiska Fila . 2010 . Analisis Kepuasan Wisatawan yang Menggunakan Jasa PT . Florensa Bali Wisata Kesiman - Denpasar . Denpasar : Program Studi D4 Pariwisata Universitas Udayana.

J.Supranto, 2006, Pengukuran Tingkat Kepuasan Pelanggan Untuk Menaikan Pangsa Pasar ,Yogyakarta : Rineka Cipta.

Kotler,Philip \& Keller, Kevin Lane ,2006 , Manajemen Pemasaran Jilid I . Terjemahan oleh Benyamin Mohan, 2009. Tanpa Kota: PT. Indeks.

Mowen, C. John dan Michael Minor. 2001. Perilaku Konsumen. Jakarta: Erlangga

Sugiyono , 2008 . Metode Penelitian Bisnis. Cetakan keduabelas . Bandung : Alfabeta

Supranto , Johanes. 2006 . Pengukuran Tingkat Kepuasan Pelanggan Untuk Menaikan Pangsa Pasar . Jakarta : Rineka Cipta.

Tjiptono,Fandy . 1997 . Strategi Pemasaran. Jakarta : Andi Offset.

Tse dan Wilson. 1988. Dalam Nasution, M. Nur. 2004. Manajemen Jasa Terpadu. Ghalia Indonesia. 